\title{
Corrigendum: Just Open Your Mind? A Randomized, Controlled Study on the Effects of Meditation on Creativity
}

\author{
lana Bashmakova* and Olga Shcherbakova \\ Department of General Psychology, Faculty of Psychology, Saint Petersburg State University, Saint Petersburg, Russia
}

Keywords: creativity, meditation, cognitive flexibility, metaphor production, cognitive control

\section{A Corrigendum on}

\section{OPEN ACCESS}

Approved by:

Frontiers Editorial Office,

Frontiers Media SA, Switzerland

*Correspondence:

lana Bashmakova

st035088@student.spbu.ru

Specialty section:

This article was submitted to

Cognition,

a section of the journal

Frontiers in Psychology

Received: 23 June 2021

Accepted: 24 June 2021

Published: 19 July 2021

Citation:

Bashmakova I and Shcherbakova O (2021) Corrigendum: Just Open Your

Mind? A Randomized, Controlled Study on the Effects of Meditation on Creativity. Front. Psychol. 12:729669.

doi: 10.3389/fpsyg.2021.729669
Just Open Your Mind? A Randomized, Controlled Study on the Effects of Meditation on Creativity

by Bashmakova, I., and Shcherbakova, O. (2021). Front. Psychol. 12:663881. doi: $10.3389 /$ fpsyg.2021.663881

In the original article, the reference for Nash et al. (2013) was incorrectly written as Nash, J. D., and Newberg, A. (2013). This has been corrected to Nash et al. (2013) throughout the article.

In the references section, Toward a unifying taxonomy and definition for meditation. Front. Psychol. 4:806. doi: 10.3389/fpsyg.2013.00806, has been corrected to: Nash, J. D., Newberg, A., and Awasthi, B. (2013). Toward a unifying taxonomy and definition for meditation. Front. Psychol. 4:806. doi: 10.3389/fpsyg.2013.00806.

The authors apologize for this error and state that this does not change the scientific conclusions of the article in any way. The original article has been updated.

\section{REFERENCES}

Nash, J. D., Newberg, A., and Awasthi, B. (2013). Toward a unifying taxonomy and definition for meditation. Front. Psychol. 4:806. doi: $10.3389 /$ fpsyg.2013.00806

Copyright (C) 2021 Bashmakova and Shcherbakova. This is an open-access article distributed under the terms of the Creative Commons Attribution License (CC BY). The use, distribution or reproduction in other forums is permitted, provided the original author(s) and the copyright owner(s) are credited and that the original publication in this journal is cited, in accordance with accepted academic practice. No use, distribution or reproduction is permitted which does not comply with these terms. 